\title{
STUDENTS' ABILITY IN UNDERSTANDING HOMOPHONE IN ENGLISH
}

\author{
Aprilisa Astri \\ IAIN Langsa \\ aprilisaastri65@gmail.com \\ Ruly Adha \\ IAIN Langsa \\ adharuly@yahoo.com
}

\section{ABSTRACT}

This research was aimed at finding out the ability of students to understand homophone in English. The research was qualitative descriptive research. The subject of the research was the seventhsemester students of the English Department of IAIN Langsa, academic year 2018/2019, that consisted of 32 students. The researchers used documentation as an instrument for collecting the data. The documentation was the result of the test given by a lecturer. The test given by the lecturer consisted of 20 questions about homophone in English. The question was in the form of phonetic transcription. The question consisted of two parts. In the first part, the students must mention two different words from a homophony sound. In the second part, the students must fill in the blank with a correct homophone word by relating to the pronunciation at the end of sentences. After conducting the research, the researchers found that 24 students got low mark because they were only able to answer one until ten questions correctly; 2 students got medium mark because they only answered 11 questions correctly, and six students got high mark because they can answer 12 until 17 questions correctly. Therefore, it can be said that the ability of students to understand homophone in English was not good enough. The problem faced by the students was that they still did not comprehend the concept of homophone in English. As a result of the test given by a lecturer, some students only knew that a homophone consisted of only one word, so they answered only one word, and some students also answered the question with three different words.

\section{Keywords}

Homophone, Sense Relation, Meaning 


\section{INTRODUCTION}

Language is systematic. The statement means that "language is arranged by some elements, which are called units of language" (Chaer, 2003,p.33-36).The units of language are arranged systematically. The arrangement of language is started from the core element (unit), namely sound; then, the group of sounds will form words, and the group of words will form sentences, and finally, the sentence must be meaningful. Therefore, the elements such as sound, word, sentence, and meaning are called units of language.

The units of language are also known as the internal elements of language. The essential element, which is regarded as the foundation of language, is sound because sound can produce other elements such as word and sentence. The most significant element that is also important in the language is meaning because meaning can determine whether the language is correct or not. The science which studies meaning is called semantics.

To comprehend meaning, we have to know the symbol, reference, and referent. A symbol is a linguistic representation which is usually in the form of word or phrase; reference is the concept or idea or characteristic which exist on human's mind; and referent is the object which can be seen or can be felt in the real world (John Lyons, 1979, p.40) (as cited in C.K. Odgen and I.A. Richards,1923) For example, the symbol (word) 'elephant' has some references (concepts), such as an animal, having four legs, having trunk; and the referent (object) is the animal which we can see in the real world.

The symbol symbolizes the reference, and the reference refers to the referent. However, there is no relation between symbol and referent. The statement means that its word does not determine the object. The word or the symbol can be various, but the object is still the same. For instance, we 
call 'elephant' for English, and 'gajab' for Babasa Indonesia, and other languages also have different symbols. Therefore, it can be said that language is arbitrary.

Because of the arbitrariness, an object can have more than one symbol. Those symbols will have a similar relation. It is what we called a sense relation. Sense relation can be defined as the semantic relationships among words. For example, the word 'answer' and 'reply' has a sense relation that we know as synonymy; the word 'big' and 'small' has a sense relation that we know as antonymy. There are some sense relations in semantics besides synonymy and antonymy, for instance, polysemy, hyponymym hypernymy, metonymy, collocation, ambiguity, homonymy, homograph, homophone, etc. In this research, the topic will be limited in homophone.

Homophone can be said to sound ambiguity. Sound ambiguity means that a sound which has two meanings. Homophone derives from Greek words 'homo' which means similar, and 'phone' means 'sound'. So, homophone can be defined as two words that have a similar sound or phonetic transcription (Yule, 2015). Homophones are words that have a similar sound, but they have different meanings and different spellings. Homophones are particularly essential to be studied because so many people use spell check programs on word processors. While spell check programs can catch many errors, these programs cannot notice a word misspelled if a homophone was used (Edward Fry and Margaret Langer, 1997). For example, the sound /mi:t/ can be realized as 'meet' or 'meat'. The word 'meet' means to visit someone (berjumpa), and the word 'meat' means flesh (daging). In short, a homophone is two words that have a similar sound or phonetic transcription but has different spelling and meaning. 
As the students who learn English for the first time, they will be difficult in understanding sense relation, especially homophone. The students will think that a sound will represent a word. However, in English, a sound can have more than one word, for example, the sound /hir/, the students will think that it is the word 'hear', but the sound also represents the word 'here'. The sound ambiguity will lead the students into an error.

The condition above can be seen in the students of the English Department in IAIN Langsa. When a lecturer gave them some questions related to the homophone, some of them fail to understand the homophony words. For example, when the lecturer instructed them to make two sentences based on the sound /wi:k/, they only know that the sound represents the word 'week', so they made a sentence 'I went to the beach last week'. However, the sound also represents the word 'weak'. They cannot think that the sound /wi:k/ is a homophone.

Based on the description above, the researchers observed the seventh-semester students of the English Department, IAIN Langsa, who had already given the material of sense relation, especially homophone. The researchers were motivated to conduct the research entitled Students' Ability in Understanding Homophone in English. In this research, the researchers wanted to find out the ability of students to understand homophone in English.

Some researchers also conducted research related to homophone. The first research, entitled 'A Study on Students' Ability in Using and Identifying English Homophone and Homograph in Sentence,' was conducted by Mohammad Zainudin Saleh. This research was aimed at describing the English students' ability to use and identifying English homophone and homograph in sentences. The method of the research was 
descriptive qualitative by using the showing and counting technique of analyzing. The researcher used a test to collect the data. In this research, the researcher found that the students' ability was not the same in each category of test. By using the formula, the researcher got a description of the students' abilities. The highest ability of students was in using homophone, and the lowest was the ability to use homograph. Then, the factor that affected the students' ability was the students' tendency to use the characteristic of Indonesian language, which is different from the characteristic of English. In Indonesian language, the way to read a word is similar to the written form, but it is different in English. The difference is that English has specific rules about certain words, especially in the phonemic domain.

In that research, Mohammad Zainudin Saleh used tests to collect the data. Meanwhile, this research used documentation and data, which were given by a lecturer, as the data. In that research, Mohammad Zainudin Saleh found that the highest ability of students was in using homophone. It can be said that the students' understanding of homophone was good. Saleh also wanted to find out the students' ability in using homograph (Saleh, 2009). Meanwhile, in this research, the researchers only wanted to find out the students' ability to use homophone. However, both of the research, Saleh's research, and this research used the descriptive qualitative method.

The second research entitled 'The Correlation between Students' Ability in Distinguishing Homophones toward Students' Listening Performance (A Study of Listening 4 Class of IAIN Salatiga in the Academic Year of 2016/2017)' was conducted by R.A. Nailufar. The objectives of this research were to find out the students' ability to distinguish homophones; to investigate the students' listening performance, and to verify the correlation between students' ability to distinguish homophones toward students' 
listening performance. This research was quantitative, and the approach used in this research was the structured approach. The subject of this research was the students of listening 4 classes of English Education Department of IAIN Salatiga. The total respondents of this research were 18 students. The data of this research were collected through tests for listening performance and distinguishing homophones ability. The collected data were tested for its validity and reliability and later analyzed using SPSS 16 for Windows. Based on the test result, the students' listening performance was categorized as failed with a mean score of 44.4. Besides, the students' ability to distinguish homophones was categorized as useful with a mean score of 71.25. The calculation of the correlation between students' ability to distinguish homophones toward students' listening performance had a correlation coefficient ( $r$ ) value of 0.193 . The result of this research showed that there was a positive correlation between students' ability to distinguish homophones toward students' listening performance even though the relationship was low. In that research, Nailufar used test to collect the data. Meanwhile, in this research, the researchers used documentation of the result of the test, which was given by a lecturer, as the data. In that research, Nailufar found that the students' listening performance was categorized as failed with a mean score of 44.4. Besides, the students' ability to distinguish homophones was categorized as useful with a mean score of 71.25. The calculation of the correlation between students' ability to distinguish homophones toward students' listening performance had a correlation coefficient ( $r$ ) value of 0.193 . Nailufar said that the students' ability to distinguish homophones was categorized as good (Nailufar, 2017). In that research, Nailufar used a quantitative method. Meanwhile, in this research, the researchers used a qualitative descriptive method. 


\section{LITERATURE REVIEW}

\section{Definition of Meaning}

The question 'What is meaning?' comes to our mind. Some linguists have described the concept of meaning. One of the linguists who describe meaning is Ferdinand de Saussure which is quoted by Abdul Chaer (2003):

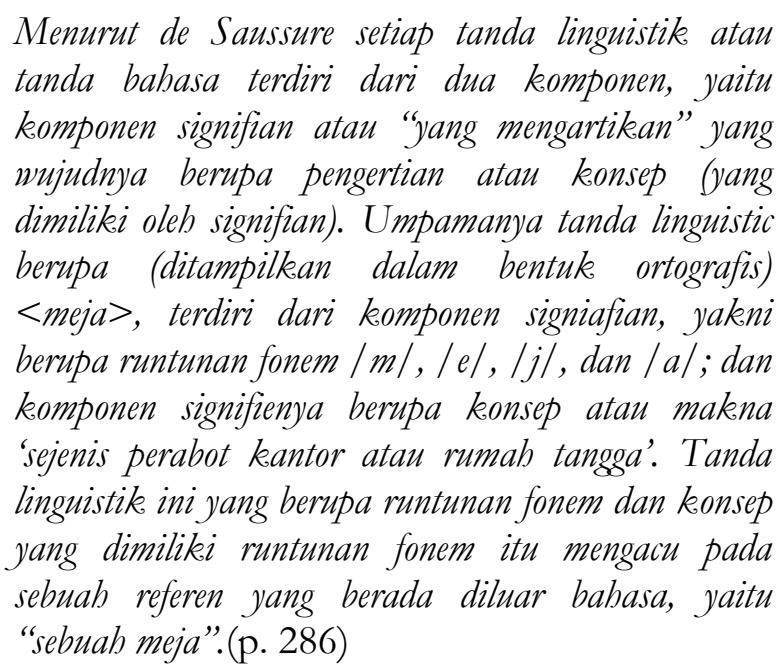

The description of meaning above given by Ferdinand de Sausure states that every linguistic sign or language sign consists of two components, i.e., signified and signifier. A signified component consists of sounds that represent the object, for example, phonemes 'table' are /t/, /eI/, /b/, /l/. The meaning or the concept of signified is called signifier. Therefore, the signifier of 'table' is a kind of household furniture.

There are three main ways in which linguists and philosophers have attempted to construct explanations of meaning in natural language.
a. by defining the nature of word meaning
b. by defining the nature of sentence meaning
c. by explaining the process of communication 
Firstly, word meaning is taken as the construct in terms of which sentence meaning and communication can be explained; in the second, it is sentence meaning which is taken as primary, with words characterized in terms of the regular contribution they make to sentence meaning. In the third, both sentence and word meaning are explained in terms of how sentences and words are used in active communication. It is no coincidence that there are these three types of explanation. In the first place, there is a relationship between words and objects. We use words to refer to objects, and to actions (consider such words as cup, horse, woman, graduate, cooking, sweeping) (Ruth, 1977).

According to de Sausure, each linguistic sign consists of two elements, namely:

a. which are interpreted (French: signifie, English: signified)

b. who interpret (French: signifiant, English: Signifier).

What is meant (signifie, signified) is nothing but the concept or meaning of a sound sign. At the same time, the meaning (signifiant, signifier) is the sounds that are formed from the phonemes of the language in question. In other words, each linguistic sign consists of sound elements and elements of meaning. These two elements are elements in the language (intralingual), which usually refer to or refer to a referent, which is an extralingual element. In the semantic field, the term commonly used for linguistic signs is lexeme, which is commonly defined as a word or phrase, which is a meaningful unit (Chaer, 2003).

Meaning can be described in theory of 'meaning triangle' which is proposed by John Lyons (1979, p.40) (as cited in C.K. Ogden and I.A. Richards, 1923). See the following diagram. 


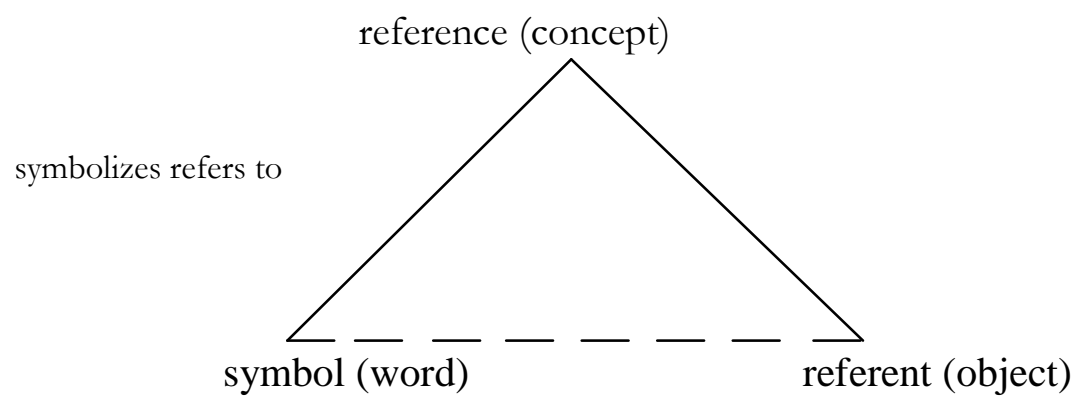

Symbol is a lingusitic representation which is usually in the form of word or phrase; reference is the concepts or characteristics or ideas which exist on the human's mind; and, referent is the object which can be seen or can be felt in the real world. For example, the word (symbol) 'horse' has some references (characteristics), namely an animal, male or female, having four legs, etc. The referent (object) of the word 'horse' is the animal that we can see in the real world.

The symbol and the reference are related to each other and also the reference and the referent. However, the symbol and the referent are not related. It shows that language is arbitrary. It means that there is no relation between word and the object. We know the word 'horse' for English, and the word 'kuda' for Bahasa Indonesia, and other languages will have different words for naming the animal, which has four legs.

Sometimes, there are some relations of meaning among words in English. We call it a sense relation. Sense relation is the semantic relation among words. For example, the word 'answer' and 'reply' has a sense relation that we know as synonymy; the word 'big' and 'small' has a sense relation that we know as antonymy. There are some sense relations in semantics besides synonymy and antonymy, for instance, polysemy, homonymy, hyponymym, collocation, meronymy, ambiguity, homophone, etc. However, in this research, homophone became the topic of discussion. 


\section{Homophone}

Homophone is words that are pronounced the same as another, but which differs in spelling and meaning, such as cite, sight, and site (Hobbs, 2006, p.3).In other words, homophone is two words pronounced alike but different in meaning. Homophone can be said as sound ambiguity. Ambiguity can be defined as having more than one meaning. Ambiguity can be found in sound, word/phrase, sentence. Ambiguity in the form of sound is also known as homophone, for example, /mi:t/can be represented into 'meat' and 'meet'. Ambiguity in the form of the word is also known as homonymy, for example, the word 'bank' has two meanings (side of the river and financial institution for keeping the money). The example of ambiguity in a sentence is 'The police hit a man with a stick'.

Homophone can be said as sound ambiguity. For example, the sound /mi:t/ can be realized as 'meet' or 'meat'. The word 'meet' means to visit someone (berjumpa), and the word 'meat' means flesh (daging). In Bahasa Indonesia, we can also find homophone, for example:

a. $/ \mathrm{m} \Lambda \mathrm{s} \Lambda /$

1. masa which means waktu (time).

2. massa which means sekumpulan orang (people).

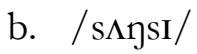

1. sanksi which means bukuman (punishment).

2. sangsi which means ragu-ragu (doubt).

In Babasa Indonesia, the concept of a homophone is not much different from the concept of homophone in English. In Bahasa Indonesia, homophone can be defined as the sameness of sound between two different words without concerning to the spelling, whether the spelling is similar or 
not. Homophone in Bahasa Indonesia can be divided into two types, namely homophone with similar spelling and homophone with different spelling.

Homophone with similar spelling can be found in the word 'bisa. The first word 'bisa' means racun (poison) and the second word 'bisa' means mampu (able). Homophone with similar spelling is also known as homonymy. Meanwhile, homophone with different spelling can be found in the word 'sangsiand 'sanksi' as given in the above example (Chaer, 2003). In short, homophone is two words which have a similar sound or phonetic transcription but has a different meaning.

\section{RESEARCH METHOD}

This research can be categorized as qualitative descriptive research. Qualitative descriptive research is research that produces descriptive data, speech or word and behavior that can be observed by the subject itself. Moleong (1991) says that the qualitative method is a procedure of the result of descriptive data in the form of written or oral words from person or activity, which is researched. Qualitative is a research method that emphasizes the aspect of an in-depth understanding of a problem rather than looking at the problem for generalization research. Qualitative research methods prefer to use in-depth analysis techniques, which is to examine a problem one by one, from the case by case. The purpose of this qualitative method is not a generalization but an in-depth understanding of a problem. The research was based on the interpretation or analysis of students' ability to understand homophone in English, and the subject was the seventhsemester students of the English Department at IAIN Langsa, academic year $2018 / 2019$. 
The primary data of this research were taken from the documentation of the result of the test, which was given to 32 students of the seventh semester of English Department academic year 2018/2019, Tarbiyah and Teacher Training Faculty, IAIN Langsa. Meanwhile, the supporting data were taken from the descriptions of some theories about homophone given by some linguists.

The researchers used documentation as an instrument to collect the data. The documentation was the result of test given by a lecturer. The test was given to 32 students of seventh semester of English Department. The test consisted of 20 questions about homophone. The question was in the form of phonetic transcription. The lecturer gave some phonetic transcriptions and the students must answer the questions by making two different words that have different meanings based on the phonetic transcriptions.

In analyzing the data, the researchers did not use any calculation or statistic procedure. The researchers did some steps as follows:

1. Data Reduction

Data Reduction means summarizing, choosing the essential topic, and focusing on the important thing. The data provided a clear description. The researchers collected critical information based on the provided questions of the topic.

2. Data Display

The data were reduced and were presented. The presentation of the data was done in the form of a brief description, charts, etc. Then, the data were organized and were arranged so that the data were easily understood. 
3. Verification (Drawing Conclusion)

Conclusion is still tentative and will change if it is not found evidence that supports the data collection. The conclusion in qualitative research may be able to answer the formulation of the research problem. However, the conclusion may not be able to answer the research problem because it is still tentative, as stated before, and the conclusion will be developed after research in the field (Sugiyono, 2009).

\section{FINDING AND DISCUSSION}

\section{Finding}

The subject of the research was the seventh-semester students of the English Department at IAIN Langsa. A lecturer gave them a test. The test consisted of two parts. In the first part, the students must mention two different words from a homophony sound. In the second part, the students must fill in the blank with a correct homophone word by relating to the pronunciation at the end of sentences. The total question in the first part was 10 questions, and in the second part, the total question was also 10 questions. 1. /mi:t/

The correct answers of the question are 'meat' and 'meet'. The students number $1,2,3,4,6,7,8,9,10,11,12,13,14,16$ answered the question correctly. Meanwhile, the students number 5, 15, 17, 18, 19, 20, 21, $22,23,24,25,26,27,28,29,30,31,32$ made an error. They only answered 'meet'.

2. / hıə(r)/

The correct answers of the question are 'here' and 'hear'. The student number 1 made an error. The student answered 'hear' and 'hire'. The word 
'hire' is not right. Meanwhile, the students number 2, 3, 4, 6, 7, 8, 9, 10, 11, $12,14,16$, answered the question correctly, 'here' and 'hear'. The student number 5 only answered 'here', and the student number 13 answered 'hair' and 'hear', the word 'hair' is incorrect. The students number 15, 17, 18, 19, $20,21,22,26,27,28,29,30,32$ only answered 'hear'. The students number 23, 25, 31 only answered 'here'. Meanwhile, the student number 24 made an error in writing the word, the student answered 'her'.

3. /wi:k/

The correct answers of the question are 'weak' and 'week'. The students number $1,2,3,4,6,7,8,9,10,11,12,13,16$ answered the question correctly. Meanwhile, the students number 5, 17, 32 only answered 'weak', and the students number 15, 18, 19, 20, 21, 22, 23, 24, 25, 26, 27, 28, 29, 30 only answered 'week', and the student number31 did not answer the question.

4. /'siəriəl/

The correct answers of the question are 'cereal' and 'serial'. The students number 1, 10answered'serial' and 'sereal'. The students made an error because the word 'sereal' is incorrect. The students number 2, 3, 4, 13, 14, 16answered the question correctly. Meanwhile, the student number5only answered 'cereal', and the students number $6,7,8,9,11,17,20,21,22,23$, 26, 27, 28, 29, 30, 32 only answered 'serial'. The students number 12, 15, 24, 25,31 only answered 'sereal', but the word is incorrect. The students number 18, 19 answered the wrong word 'sireal'.

5. /blu:/

The correct answers of the question are 'blue' and 'blew'. Student number 1 answered 'blue' and 'blouse'. The word 'blouse' is incorrect. Meanwhile, the students number 2, 3, 4, 14,16answered the question 
correctly, and the students number $5,6,7,8,9,10,11,12,15,17,18,19,20$, $21,22,23,24,25,26,27,28,29,30,31,32$ only answered 'blue'. The student number 13 answered 'blue' and 'bloom'. The word 'bloom' is incorrect.

$6 . / \mathrm{sel} /$

The correct answers to the question are 'sell' and 'cell'. The student number 1 answered 'sell' and 'seil'. The word 'seil' is incorrect. Meanwhile, the students number 2, 4 answered 'sale' and 'cell'. The word 'sale' is incorrect. The students number 3, 6, 7, 9, 10, 11, answered the question correctly, and the students number 5, 12, 15, 31 only answered 'cell'. The students number 8, 13, answered 'sell' and 'shell'. The word 'shell' is incorrect. The student number 14 answered 'cell' and 'sel'. The student answered incorrectly on the word "sel". Meanwhile, the student number 16 answered 'sell' and 'sall'. The word 'sall' is incorrect. The students number 17, 18, 19, 24, 26, 27, 28, 29, 30, 32 only answered 'sel'. The students number 20, 21, 22 only answered 'shall'. The students number 23, 25 only answered 'cel'. The students number 24, 26, 32 only answered 'sel'.

7. /nait/

The correct answers of the question are 'night' and 'knight'. The students number 1, 2, 3, 6, 14, 16 answered the question correctly. Meanwhile, the student number 4only answered 'night', and the student number 5only answered 'not'. The students number 7, 8 answered 'night' and 'nigh'. The word 'nigh' is incorrect. The students number 9, 11 answered the question with three different words 'night', 'nigh', and 'knight'. The student number 10 answered the question with three different words 'not', 'night', and 'knight'. The student number 12 answered 'night' and 'nut'. The word 'nut' is incorrect. The student number 13only answered 'nut'. The students number 15, 17, 20, 21, 22, 23, 24, 25, 26, 27, 28, 29, 32 only answered 'night'. 
The students number 18, 19 only answered 'nait'. The student number 30only answered 'nail', and the student number 31only answered 'nait'.

8. /hi:l/

The correct answers of the question are 'heel' and 'heal'. The students number 1, 12, 13 answered 'hill' and 'heal'. The word 'hill' is incorrect. The students number 2, 3, 4, 7, 8, 10, 14 answered 'hill' and 'heel'. The word 'hill' is incorrect. The students number $5,22,23,24,25,26,27,28,29,30,32$ only answered 'heel'. Meanwhile, the students number 6, 9, 11, answered the question with three different words 'heal', 'heel', and 'hill'. The student number 15 only answered 'heal'. The student number 16 answered the question correctly. The student number 17 only answered 'heel'. The students number 18, 19, 31only answered 'hill'. The students number 20, 21 only answered 'hell'.

9. /bea(r)/

The correct answers of the question are 'bare' and 'bear'. The students number 1 answered 'beer' and 'bir'. The word 'bir' is incorrect. The students number $2,4,5,12,15,18,19,20,21,22,23,24,25,26,27,28,29$, 30, 31, only answered 'bear'. The student number 3, 6, 8, 10, 11, 16 answered 'bear' and 'beer'. The word 'beer' is incorrect. Meanwhile, the student number 7, 9, 14 answered 'bear' and 'beard'. The student number 13 answered 'bear' and 'br'. The word 'br' is incorrect. The students number 17, 32,only answered 'beer'.

10. /fli:/

The correct answers to the question are 'flee' and 'flea'. The student number 1 answered 'flee' and 'flew'. The word 'flew' is incorrect. The students number $2,3,7,8,9,14,16$ answered the question correctly. The students number 4, 12, 15 only answered 'flea'. The students number 5, 18, 
19, 20, 21, 22, 24, 26 only answered 'fly'. Their answer was incorrect. Meanwhile, the students number 6, 11, 17, 25, 27, 28, 29, 30, 32 only answered 'flee'. The student number 10 answered 'fly' and 'flee'. The word 'fly' is incorrect. The student number 13only answered 'flip'. The word 'flip' is incorrect, and the student number 23only answered 'flie'. The word 'flie' is incorrect. The student number 31 did not answer the question.

11. /bi:/

The correct answer of the question are 'be' and 'bee'. The students number 1, 2, 3, 4, 5, 6, 7, 8, 9, 10, 14, 16, 24, 25, 26, 27, 28 answered the question correctly. The students number 11, 19 only answered 'be'. Meanwhile, the students number 12, 13, 15 answered 'be' and 'bea'. The word 'bea' is incorrect. The students number 17, 18, 23, 29, 30, 31, 32 answered with two similar words. The students number 20, 21, 22 answered 'be' and 'by'. The word 'by' is incorrect.

12. /həol/

The correct answer of the question is 'hole'. The students number 1, $2,3,5,6,7,8,9,10,11,14,16,23,24,25,26,27,28$ answered the question correctly. Meanwhile, the student number 4 answered 'hell'. The students number 12, 13, 15only answered 'whole', and the students number 17, 18, 19, 30, 32 did not answer the question. The students number 20, 21, 22 answered 'hell'. The word 'hell' is incorrect. The student number 29 answered 'hoel'. It is incorrect. The student number 31 answered 'hill'. The word 'hill' is incorrect.

13. /si:/

The correct answer of the question are 'see' and 'sea'. The students number 1, 2, 3, 4, 5, 6, 7, 8, 9, 10,11, 12, 13, 14, 15, 16, 18, 19, 20, 21, 22, 23, $24,25,26,27,28,29,32$ answered the question correctly. Meanwhile, the 
students number 17, 31 answered the question with two similar words, 'see'. The student number 30 answered the question with two similar words, 'sea'. 14. /haI/

The correct answer is 'high'. The students number 1, 2, 3, 4, 6, 7, 8, 9, $10,11,12,13,15,17,20,21,22,26,27,28,29,30,31,32$ answered the question correctly. The student number 5 answered the question incorrectly. The student answered 'haig'. Meanwhile, the student number 14 answered 'height'. The students number 16, 23, 24, 25 answered 'hight'. The student number 18 answered 'hi'. The student number 19 did not answer the question.

15. $/ \mathrm{s} \Lambda \mathrm{n} /$

The correct answer are 'sun' and 'son'. The students number 1, 2, 3, $4,5,6,7,8,9,10,11,12,13,14,15,16,17,20,21,22,26,27,28,31,32$ answered the question correctly. Meanwhile, the students number 18, $19 \mathrm{did}$ not answer the question. The students number 23, 24, 25answered the question incorrectly. They answered 'sun' and 'sand'. The student number 29 answered the question incorrectly. The student answered 'sun' and 'so', and student number 30 answered a similar word.

16. /raIt/

The correct answer is 'right'. The students number 1, 2, 3, 4, 6, 7, 8, $9,10,11,14,17,20,21,22,23,24,25,26,27,28,29,30,31,32$ answered the question correctly. Meanwhile, the students number 5, 12, 13, 15answered 'write'. The student number 16 answered 'vight'. The students number 18, 19 did not answer the question.

17. /breik/

The correct answers are 'brake' and 'break'. The student number 1 answered the question correctly. Meanwhile, the students number 2, 3 
answered 'breach' and 'break'. The word 'breach' is incorrect. The student number 4 answered 'break', but the position of the answer is incorrect. The student number 5 answered 'break' and 'broke', and the students number 6, $7,8,9,10,11,12,13,16,17,20,21,22,23,24,25,26,27,28,29,30,31,32$ answered two similar words, 'break'. The students number 14, 15only answered 'break'. The students number 18, 19 did not answer the question. 18. /aI/

The correct answer is 'eye'. The student number 1 answered the question incorrectly. The students number $2,3,4,5,6,9,11,12,13,14,15$, $16,20,21,22,23,24,25,26,27,28,32$ answered the question correctly. Meanwhile, the student number 7 answered the question incorrectly, 'aye'. The student number 8 answered the question incorrectly, 'eyes'. The student number 10 answered the question incorrectly, 'age'. The students number 17, 18, 19 did not answer the question. The student number 29 answered the question incorrectly, 'all'. The student number 30 answered 'on'. The student number 31 answered 'aight'.

19. / nov/

The correct answer of the question is 'no'. The student number 1 answered the question incorrectly, 'now'. The students number 2, 3, 14, 17, 29, 32 answered the question correctly. Meanwhile, the students number 4, 5, $6,7,8,9,10,11,12,13,15,16,20,21,22,23,24,25,26,27,28,31$ answered 'new'. The students number 18, 19, $30 \mathrm{did}$ not answer the question.

20. / rovl/

The correct answer of the question is 'role'. The student number 1 answered the question incorrectly, 'real' and 'role'. The students number 2, 3, $4,12,13,14,15,20,21,22,23,24,25,26,27,28$, answered the question correctly. Meanwhile, the student number 5 answered 'role' and 'rool'. The 
students number 6, 7, 8, 9, 11 answered 'rule' and 'role'. The students number 10, 3, 32 answered 'real' and 'roll'. The student number 16 answered 'real' and 'reel'. The student number 17 only answered 'roel'. The students number 18, 19, 30 did not answer the question. The student number 29 answered 'roel' and 'roll'.

\section{Discussion}

Based on the finding which has been described by the researchers, it can be seen that the ability of seventh semester students of English Department at IAIN Langsa is not good enough. Many students made some errors in understanding homophone in English.

The student number 1 until 32 answered the 20 questions. The writer analyzed that the students number 1, 8, 10, 11 answered 10 questions correctly. The student number 2 answered 16 questions correctly. The student number 3 answered 17 questions correctly. The students number 4, 7 answered 11 questions correctly. The students number 5, 15, 23answered 5 questions correctly. The students number 6, 9 answered 12 questions correctly. The students number 12, 13, 26, 27, 28 answered 8 questions correctly. The student number 14 answered 14 questions correctly. The student number 16 answered 13 questions correctly. The students number 17, 29 answered 4 questions correctly. The students number 18, 19 answered 1 question correctly. The students number 20, 21, 24, 25, 32 answered 6 questions correctly. The student number 22 answered 7 questions correctly. The students number 30, 31 answered 2 questions correctly. In short, the total number of students who answered the questions correctly can be seen as follows: 

a. 2 students (number 18, 19) answered 1 question correctly.
b. 2 students (number 30,31) answered 2 questions correctly.
c. 2 students (number 17,29) answered 4 questions correctly.
d. 3 students (number 5, 15, 23) answered 5 questions correctly.
e. 5 students (number 20, 21, 24, 25, 32) answered 6 questions correctly.
f. 1 student (number 22) answered 7 questions correctly.
g. 5 students (number 12, 13, 26, 27, 28) answered 8 questions correctly.
h. 4 students (number 1, 8, 10,11) answered 10 questions correctly.
i. 2 students (number 4,7 ) answered 11 questions correctly.
j. 2 students (number 6,9 ) answered 12 questions correctly.
k. 1 student (number 16) answered 13 questions correctly.
1. 1 student (number 14) answered 14 questions correctly.
m. 1 student (number 2) answered 16 questions correctly.
n. 1 student (number 3) answered 17 questions correctly.

There were 6 students who answered $12-17$ questions correctly and they got high mark; 2 students answered 11 questions correctly and they got medium mark, and 24 students who answered 1 - 10 questions correctly and they got the low mark. Therefore, the researchers gave an answer that the ability of students in understanding homophone in English was not good enough. Some students only knew that a homophone consisted of only one word, so they answered only one word. Some students also answered the question with three different words. In short, the students still did not comprehend the concept of homophone in English.

\section{CONCLUSION}

From the finding, the researchers concluded the total number of students who had answered the questions correctly in the following table. 

Journal of Linguistics, Literature \& Language Teaching

\begin{tabular}{|c|c|}
\hline $\begin{array}{l}\text { The Number of } \\
\text { Question }\end{array}$ & $\begin{array}{c}\text { The Total Number of Student who Answers } \\
\text { the Question Correctly }\end{array}$ \\
\hline 1 & 12 students \\
\hline 2 & 12 students \\
\hline 3 & 13 students \\
\hline 4 & 6 students \\
\hline 5 & 5 students \\
\hline 6 & 6 students \\
\hline 7 & 6 students \\
\hline 8 & 1 student \\
\hline 9 & - \\
\hline 10 & 7 students \\
\hline 11 & 17 students \\
\hline 12 & 18 students \\
\hline 13 & 29 students \\
\hline 14 & 24 students \\
\hline 15 & 25 students \\
\hline 16 & 25 students \\
\hline 17 & 1 student \\
\hline 18 & 22 students \\
\hline 19 & 6 students \\
\hline 20 & 16 students \\
\hline
\end{tabular}

From the analysis, the researchers found that 24 students got low mark because they were only able to answer 1 until 10 questions correctly; 2 students got medium mark because they only answered 11 questions correctly; and 6 students got high mark because they can answer 12 until 17 
questions correctly. Therefore, it can be said that the ability of students in understanding homophone in English was not good enough. The problem that faced by the students was they still did not comprehend the concept of homophone in English. As stated in the literature review, homophone is words that have similar pronunciation, but they differ in spelling and meaning. In the result of the test given by a lecturer, some students only knew that a homophone consisted of only one word, so they answered only one word, and some students also answered the question with three different words.

\section{REFERENCES}

Adisutrisno, W. (2008). Semantics. Yogyakarta: Penerbit Andi.

Bloomfield, L. (1933). Language. New York: Holt, Rinehart, and Winston, Inc.

Chaer, A. (2002). Pengantar Semantik Bahasa Indonesia. Jakarta: Rineka Cipta.

Chaer, A. (2003). Linguistik. umum. Jakarta: Rineka Cipta.

Fry, E. \& Langer, M. (1997). Homophones workbook (grade 3-6). Westminster: Laguna Beach Educational Book.

Hobbs, J. B. (2006). Homophones and Homographs: An American dictionary (4th ed). New York: McFarland \& Company.

Leech, G. (1977). Semantics. London: Cambridge University Press.

Lyons, J. (1979). Semantics. London: Cambridge University Press.

Moleong, L. J. (1991). Penelitian Kualitatif. Bandung: Remaja Karya.

Nailufar, R.A. (2017). The correlation between students' ability in distinguishing Homophones toward students' listening performance (A study of listening 4 class of IAIN Salatiga in the academic year of 2016/2017). Salatiga: IAIN 
Salatiga.

Palmer, F.R. (1981). Semantics. London: Cambridge University Press.

Parera, J.D. (2004). Teori Semantik. Jakarta: Erlangga.

Pateda, M. (1988). Linguistik: Sebuab pengantar. Bandung: Angkasa.

Ruth, K. (1977). Semantics theory. New York: Cambridge University Press.

Saleh, M. Z. (2009). A study on students' ability in using and identifying English Homophone and Homograph in sentence. Gorontalo: Universitas Negeri Gorontalo.

Sugiyono. (2009). Metode Penelitian Kuantitatif, Kualitatif dan R \& D. Bandung: Alfabeta.

Yule, G. (1996). The study of language. London: Cambridge University Press.

Yule, G. (2015). Kajian Bahasa (terj.). Yogyakarta: Pustaka Pelajar. 